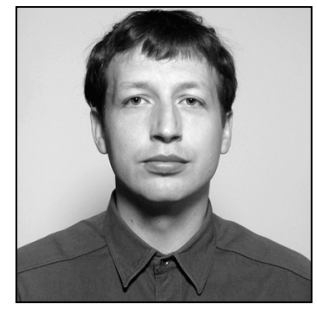

Kaarel Relve

LLM, Lecturer of Environmental Law

University of Tartu

\title{
The Subjective Right to Environment in the General Part of the Environmental Code Act
}

Human existence and quality of life depend on the environment. It is evident that everyone has an interest in using the environment and protecting him- or herself from risks or harm to the environment. However, it is not clear how this interest has to be guaranteed by rights. One possibility is the recognition of an independent material enforceable subjective right to environment. In June 2010, the Supreme Court held that such a right cannot be derived from the Constitution of the Republic of Estonia and can emerge only if criteria for the quality of the environment and everyone's obligation to tolerate environmental impacts can be fixed in the law. The General Part of the Environmental Code Act (GPECA) ${ }^{* 1}$ entered into force on 1 August 2014, and its §23 sets out a subjective right to environment. The purpose behind this paper is to examine the basis for that right and analyse its scope and contents to determine whether it satisfies the criteria outlined by the Supreme Court.

\section{The basis for the subjective environmental right in the GPECA}

\subsection{The framework of international and EU law}

The Universal Declaration of Human Rights (1948) does not feature a subjective environmental right and does not emphasise the importance of a supportive environment for enjoyment of the rights enshrined in the declaration. The environmental aspects of human rights are also not reflected in other classical human rights instruments. At the time of their codification, knowledge of environmental problems was limited and other issues were at the centre of concern. For instance, the European Convention on Human Rights (1950) was adopted as a response to the atrocities committed by Nazi Germany and the rise of communism. ${ }^{{ }^{2}}$

Awareness of environmental issues rapidly increased in the decades following the Second World War. This led to the adoption of the Stockholm Declaration (1972), whose first principle stipulates: 'Man has the fundamental right to freedom, equality and adequate conditions of life, in an environment of a quality that

1 Keskkonnaseadustiku üldosa seadus. - RT I, 28.2.2011,1 (in Estonian). English text available at https://www.riigiteataja. ee/en/eli/517062015001/consolide (most recently accessed on 31.3.2016).

2 S. Kravchenko, J.E. Bonine. Interpretation of human rights for the protection of the environment in the European Court of Human Rights. - Pacific McGeorge Global Business \& Development Law Journal 2012 (25) / 1, p. 248. 
permits a life of dignity and well-being, and he bears a solemn responsibility to protect and improve the environment for present and future generations." ${ }^{*} 3$

Regional human rights conventions and national constitutions adopted after the Stockholm Declaration usually mention a right to environment. ${ }^{*}{ }^{4}$ An exceptional reference to the right is found in the Århus Convention, which was drafted under the auspices of the United Nations Economic Commission for Europe. ${ }^{*}$ Article 1 of that convention stipulates that each party thereto has to guarantee certain procedural rights to the public in order to contribute to protection of the right of every person of present and future generations to live in an environment adequate for his or her health and well-being. In other words, the Århus Convention does not expressly state that the right exists but does refer to it as an accepted fact. However, it is doubtful that there is consensus on the existence of such a material right, let alone on its precise contents. ${ }^{* 6}$ International attention has been directed primarily at the relationship of the environment with already recognised human rights rather than proclamation of a new right. ${ }^{* 7}$

This process of 'greening of rights' is also evident in the practice of the European Court of Human Rights. The text of the European Convention on Human Rights does not reflect environmental concerns. However, the Court considers that convention to be a living instrument, to be interpreted in the light of present-day conditions. ${ }^{*} 8$ It has found violations of several articles of the conventions in connection with environmental matters, most notably Article 8, which sets out the right to respect for private and family life. Nonetheless, the Court has stressed that there is no explicit right referred to in the convention to a clean and quiet environment and that environmental human rights are not given special status in weighing of interests under Article 8. ${ }^{*} 9$ Also, Article 8 does not protect against general deterioration of the environment if there is no harmful effect on a person's private or family sphere. ${ }^{* 10}$

The EU treaties and the EU Charter of Fundamental Rights do not recognise a subjective material right to environment. However, the EU is party to the Århus Convention and environmental procedural rights are provided for under EU directives and regulations. Substantive environmental issues are also extensively regulated in EU secondary law, primarily by directives. The directives set out requirements for Member States in order to protect the environment and public health and to ensure the functioning of the internal market. The directives do not explicitly confer material rights upon individuals, but, according to the doctrine of direct effect, a person in a dispute with a public body of a Member State may rely directly on only those provisions of directives that are unconditional and sufficiently precise. ${ }^{*}{ }^{11}$ Many environmental requirements fail this test because they set out general obligations that leave significant discretion to Member States in implementing them. However, certain environmental quality provisions are directly effective. The Court has held that whenever the failure to observe the measures required by the directives that are related to air quality and drinking water, where these are designed to protect public health, could endanger human health, the persons concerned must be in such a position that they can rely on the mandatory rules included in those directives. ${ }^{{ }^{112}}$ It is not clear which members of the public (if any) could rely on other

3 Declaration of the United Nations Conference on the Human Environment. Available at http://www.unep.org/documents. multilingual/default.asp?documentid=97\&articleid=1503 (most recently accessed on 30.3.2016).

4 UN Human Rights Council. Report of the Independent Expert on the issue of human rights obligations relating to the enjoyment of a safe, clean, healthy and sustainable environment. J. H. Knox. 24.12.2012 (A/HRC/22/43), p. 5.

5 The UN Convention on Accession to Information, Public Participation in Decision-making and Access to Justice in Environmental Matters was opened for signature at the 4th Conference of Ministers of Environment in Århus on 25 June 1998. The convention entered into force on 30 October 2001. It is available at http://www.unece.org/env/pp/treatytext.htm (most recently accessed on 31.3.2016). The EU and all its member states have acceded to the convention. Information on the status of ratification is available at http://www.unece.org/env/pp/ratification.html (most recently accessed on 30.3.2016).

6 For instance, the United Kingdom made a declaration upon signature of the Århus Convention that, while it understands the references to the right to express an aspiration that motivated the negotiation of that convention, the legal rights that each party thereto undertakes to guarantee under Article 1 are limited to procedural rights. Declarations and reservations are available at http://www.unece.org/env/pp/ratification.html (most recently accessed on 30.3.2016).

7 Report by J.H. Knox (see Note 4), p. 7.

8 See, e.g., ECHR 25.4.1978, Tyrer $v$. The United Kingdom (application 5856/72), para. 31.

9 See, e.g., ECHR [Grand Chamber] 8.7.2003, Hatton and others $v$. The United Kingdom (application No. 36022/97), paras 96 and 122.

10 ECHR 22.5.2003, Kyrtatos v. Greece (application 41666/98), paras 52-53.

11 See, e.g., ECJ 23.2.1994, C-236/92, Comitato di Coordinamento per la Difesa della Cava and others v. Regione Lombardia and others, para. 8.

12 See ECJ 30.5.1991, C-361/88, Commission v. Germany; 30.5.1991, C-59/89, Commission v. Germany; 17.10.1991, C-58/89, Commission v. Germany; 25.7.2008, C-237/07, Janecek v. Freistaat Bayern. 
unconditional and sufficiently precise environmental protection requirements, especially the nature protection provisions. However, it seems unlikely that the criterion of 'being concerned' would be interpreted restrictively by the Court. ${ }^{*} 13$

The direct applicability of certain environmental quality requirements set forth in the directives does not mean that the Court has recognised a subjective material environmental right. The aim behind the doctrine of direct effect of directives is to ensure legal integration and effectiveness of EU law, which also underpinned the Court's original articulation of the direct effect of treaty provisions. However, EU law would certainly play an important role in any national attempt to define a material environmental right, by setting out the minimum requirements for many aspects of environmental quality.

\subsection{Constitutional provisions for the environment}

Unlike the majority of modern constitutions in this respect ${ }^{* 14}$, the Constitution of the Estonian Republic ${ }^{* 15}$ does not explicitly recognise a subjective right to environment. Section 5 sets out that the natural wealth and resources of Estonia are national riches that must be used sustainably. This is a general provision that underscores the value of the environment and is considered to form the basis for a duty of the state to protect the environment. ${ }^{*} 6$ The first sentence of $\S 53$ stipulates that everyone has a duty to preserve the human and natural environment and to compensate for harm that he or she has caused to the environment. Whilst this is a provision for a fundamental duty, its ambiguous wording casts doubt on whether it has any direct effect. ${ }^{*} 17$

The lack of explicit reference to an environmental right does not mean that the drafters of the Constitution were not concerned about environmental impacts on human life. In the final year of existence of the Soviet Union (1991), the Constitutional Assembly (also 'the Assembly' below) was formed and tasked with drafting of the Constitution. ${ }^{*}{ }^{18}$ An environmental right was debated on several occasions during the discussions by the Assembly ${ }^{*}$, and the first 'final' draft that was made public, in late 1991, explicitly recognised the right to a healthy environment. ${ }^{* 20}$ That right was later edited out. The reasons for this decision are not clear, because the minutes of the meetings are incomplete. In the earlier discussions, some drafters voiced a concern that the right was too ambiguous. ${ }^{{ }^{2} 21}$ The decision may also have been influenced by somewhat naïve thinking (in retrospect) that the emphasis must instead be on the fundamental environmental duty, because after privatisation of industry the state no longer has an important role in controlling environmental pollution. ${ }^{* 22}$ Although the reference to a healthy environment was deleted, the right to health protection was retained in the Constitution as adopted: the first sentence of $\$ 28$ states that everyone is entitled to protection of his or her health.

The Århus Convention, which Estonia ratified in 2001, had a significant impact on Estonian legal thinking about environmental rights, including the basic environmental right. Some authors proposed that the

13 The court is clearly in favour of enabling the public to play an active role in environmental protection in disputes with Member States, as can be seen from the decisions on interpretation of provisions of directives that implement access to justice requirements of the Århus Convention. For examples, see ECJ 11.4.2013, C-260/11, David Edwards, Lilian Pallikaropoulos v. Environment Agency, First Secretary of State, Secretary of State for Environment, Food and Rural Affairs; ECJ 16.4.2015, C-570/13, Karoline Gruber $v$ Unabhängiger Verwaltungssenat für Kärnten, EMA Beratungs- und Handels GmbH, Bundesminister für Wirtschaft, Familie und Jugend.

14 D.R. Boyd. The Environmental Rights Revolution: A Global Study of Constitutions, Human Rights and the Environment. Vancouver: UBC Press 2012, pp. 47, 59.

15 Eesti Vabariigi Põhiseadus. - RT I, 15.5.2015, 2 (in Estonian). English text available at https://www.riigiteataja.ee/en/ eli/521052015001/consolide (most recently accessed on 31.3.2016).

16 Ü. Madise et al. Eesti Vabariigi põhiseadus. Kommenteeritud väljaanne ['Commentary on the Constitution of the Estonian Republic']. Tallinn: Juura 2012, pp. 88-89.

17 Ibid., p. 489.

18 For an overview of the formation of the assembly and the drafting process, see I. Hallaste. Eesti Vabariigi põhiseaduse sünd ['The birth of the Constitution of the Republic of Estonia']. - Juridica 1996 (IX), pp. 438-442.

19 Põhiseadus ja Põhiseaduse Assamblee. Koguteos ['The Constitution and Constitutional Assembly, Unabridged Edition']. Tallinn: Juura, Õigusteabe AS 1997. See, e.g., pp. 427, 430, 434, 483-489.

20 Section 36 of the draft set out that "[e]veryone has a right to health protection and to a healthy work and living environment. Every person, agency, undertaking, and organisation has the duty to compensate for harm done to the natural and living environment by illegal acts'. Draft Constitution of 13th December 1991 of the Constitutional Assembly. Ibid., p. 1207.

21 See, e.g., the statements of V. Rumessen, J. Adams, and I. Hallaste. Ibid. (on pages 470, 486, and 487, respectively).

22 For examples, see the statements of T. Käbin and A. Tarand. Ibid. (on p. 433 and pp. 483-484, respectively). 
basic right can be derived from the Constitution even in the absence of express reference to such a right. According to one of the more articulate opinions, the duty set out in $\$ 53$ of the Constitution includes the state and, also, a state duty that serves individuals' interests and is formulated in the chapter on basic rights has to give rise to a subjective right. ${ }^{{ }^{2} 3} \mathrm{I}$ too am of the opinion that it is possible to derive the right from the state duty and that recognising that right would be in the spirit of the Constitution. The enforceability of the right would probably be limited in consequence of its indeterminate nature; nonetheless, recognition of the basic right would have important symbolic value and it would influence the interpretation of provisions of ordinary laws, especially procedural requirements. ${ }^{24}$ However, there is no general agreement as to the existence or the exact constitutional basis of the right. ${ }^{* 25}$

The lack of explicit reference to an environmental right in the Constitution did not deter some administrative courts from recognising that right in order to allow standing before the court. According to $\S 15$ of the Constitution and $\S 44$ of the Code of Administrative Court Procedure ${ }^{*_{2} 6}$, the right of action is based on the protection of subjective rights. Violation of subjective rights is understood in light of the protective norm theory. According to that theory, a violation of a provision of public law results in violation of a person's subjective right only when the violated provision protects the person's interest. In the decision on whether a person has a subjective right, both the aim with the violated norm and the weight of the person's interest must be considered. ${ }^{*} 7$

In legal practice, it would have been difficult for the complainant to demonstrate a violation of a traditional subjective right, such as a right to ownership. Therefore, some courts, especially the Tallinn Circuit Court, took the position that standing can stem directly from a violation of the basic environmental right. ${ }^{{ }^{2} 8}$ The Tallinn Circuit Court has held that, on account of $\$ 5$ of the Constitution, 'there is no real reason to doubt that the Constitution imposes a duty to protect the environment on the state and on the agencies of a local municipality. The duty not just is objective but creates a subjective right to demand from the public authority the preservation of the environment at least in the event that it affects one's living environment'. The Court reasoned that it is evident from the Constitution that the state duty is imposed for the benefit of every inhabitant of Estonia. Also, $\S 10$ of the Constitution encourages recognition of new rights, ${ }^{* 29}$ especially if those rights are generally accepted in the European region, such as the right referred to in Article 1 of the Århus Convention. It should be noted also that the right is recognised in many other national constitutions and that the EU Charter of Fundamental Rights requires a high level of environmental protection. ${ }^{*} 30$

The subjective basic right was not recognised by all courts. ${ }^{*}{ }^{31}$ It is important to note that the Supreme Court neither acknowledged nor denied the existence of the right for a long time. Instead, the Supreme Court extended standing in connection with environmental matters in 2007 by allowing filing of complaints not only on the basis of a violation of a subjective right but also on the basis of being directly concerned i.e., on the basis of certain interests. ${ }^{*} 32$ The legal basis for the exceptional standing and its extent were not

23 A. Andersson, T. Kolk. The role of basic rights in environmental protection: Basic right to environment de lege ferenda in the Estonian Constitution. - Juridica International 2003 (VIII), pp. 147-148.

24 I have expressed my views on the matter in a now somewhat outdated article written in Estonian: K. Relve. Füusiliste isikute subjektiivne õigus ja põhjendatud huvi keskkonnasjades ['The subjective right and legitimate interests of natural persons in environmental matters']. - Juridica 2004 (I), pp. 20-31.

25 For instance, the notion that a subjective right can simply arise from a state duty has been criticised. L Kanger. Kas EV põhiseaduses sisaldub õigus puhtale keskkonnale ['Does the Estonian Constitution include a right to a healthy environment?']. - Akadeemia 2007/11.

26 Halduskohtumenetluse seadustik. - RT I, 23.2.2011, 3 (in Estonian). English text available at https://www.riigiteataja.ee/ en/eli/506042016001/consolide (most recently accessed on 31.3.2016).

27 SCSCd 20.12. 2000, 3-3-1-15-01, para. 22.

28 See, e.g., Tallinn CCd 15.12.2004, 2-3/140/04; Tallinn CCr 13.8.2007, 3-07-102; Tallinn CCd 18.3.2008, 3-06-1136; Tallinn CCd 26.6.2008, 3-06-188.

29 Section 10 of the Constitution stipulates: 'The rights, freedoms and duties set out in the chapter of basic rights and obligations do not preclude other rights, freedoms and duties which arise from the spirit of the Constitution or are in accordance therewith, and which are in conformity with the principles of human dignity, social justice and democratic government founded on the rule of law.'

30 Tallinn CCd 18.3.2008, 3-06-1136, paras 8-10.

31 See, e.g., the overview of the relevant practice of administrative courts until 2006 offered by K. Vaarmari. Keskkonnaalane subjektiivne õigus Eesti kohtupraktikas ['The subjective environmental right in Estonian court practice']. - Juridica 2007 (VII).

32 ALCSCd 28.2.2007, 3-3-1-86-06, para. 16. 
clear, although the Court explicitly denied actio popularis. ${ }^{*} 3$ However, in 2010 the Supreme Court finally tackled the question of the existence of a basic environmental right. The Court held that the environment is an important value for everyone but that an enforceable independent subjective environmental right cannot be derived directly from $\S \S 5$ and 55 . In the Court's opinion, a right to a clean environment can emerge as an independent subjective right if the criteria for such an environment and everyone's obligation to tolerate environmental impacts can be fixed in the law. Currently the legal criteria are manifestly inadequate for determining the extent to which the right can be protected. ${ }^{*} 34$

\subsection{The relationship of the GPECA's $\$ 23$ with the legal framework and court practice}

Estonian environmental law has been in the process of codification since 2007. The process involves not just the consolidation and systematisation of existing law but also a critical review of the law, tackling of contradictions, and bridging of gaps; in other words, the codification is substantive. ${ }^{*} 35$ The General Part of the Environmental Code was adopted in 2011; however, the special part of the code has not been completed yet. ${ }^{*} 36$

The subjective right to environment is set out in the GPECA's §23. The link with the Århus Convention is obvious from the wording of the name of the right - referring to a right to an environment that meets health and well-being needs - which is almost identical to the formulation of the right in the Estonian translation of the convention. However, according to the explanatory memorandum accompanying the draft GPECA, the intention was to set out a material right ${ }^{*} 37$ rather than provide only procedural guarantees.

The explanatory memorandum states that the aim in stipulating the GPECA's $\$ 23$ is to specify the basic right that has been recognised in court practice. ${ }^{*}{ }^{3}$ This statement may appear puzzling since the Supreme Court had rejected the right in 2010. The apparent contradiction can be explained through examination of the timeline of codification. Initially the code was intended to be adopted as a unified entity; however, because of the approaching 2011 general elections, consultations on the draft GPECA began on 13 May 2010. ${ }^{*} 39$ The Supreme Court delivered the judgement in June after the consultation process. Parliamentary proceedings were initiated on 13 September 2010. ${ }^{*} 40$ The Parliament was aware of the decision; however, it did not alter the wording of §23. It should be noted that the Parliament too was under time pressure because of the impending elections. The GPECA was adopted on 28 February 2011, and the general election was held in March.

\section{Elements of the subjective environment right in the GPECA}

\subsection{The concept of environment}

The GPECA's §23 entitles everyone to a certain environment but does not define the concept of 'environment'. No universal legal definition of this concept exists; the elements of conventional definitions depend on the aims of the legislator. ${ }^{*}{ }^{41}$ In the broadest sense, the term signifies surroundings, including social

33 Ibid. Note that the practice was discontinued in 2015 on account of the entry into force of the GPECA's §23. See ALCSCr 13.5.2015, 3-3-1-8-15, paras 19-21.

34 ALCSCr 18.6.2010, 3-3-1-101-09, para. 13.

35 See the explanatory memorandum to the GPECA, p. 2. Available at http://www.riigikogu.ee/?page=eelnou\&op=ems\&ems help=true\&eid $=1147282 \& u=20110616182716$ (most recently accessed on 31.3.2016) (in Estonian).

36 At the time of writing of this article, in March 2016, the majority of the codified specific laws, such as the Water Act, are still in the draft stage. The deadline for the completion of the Special Part has been postponed several times.

37 See the memorandum referred to in Note 35, p. 29.

38 Ibid., pp. 29-30.

39 Letter of the Minister of Justice of 13.5.2010, No. 10.2-1/7346. Available at http://eelnoud.valitsus.ee/main\#ICKKooSf (most recently accessed on 31.3.2016) (in Estonian).

40 Information on the parliamentary proceedings for the draft is available at http://www.riigikogu.ee/tegevus/eelnoud/eelnou/ a1cafc27-2f02-448d-8509-8e9fa312a129/ (most recently accessed on 30.3.2016) (in Estonian).

41 See, e.g., F. Fracchia. The legal definition of environment: From rights to duties. Bocconi Legal Studies Research Paper No. 06-09, 2005. - DOI: http://dx.doi.org/10.2139/ssrn.850488. 
and psychological elements. The focus of the GPECA is not so broad, which is evident from several of the act's provisions, especially the definitions of 'environmental information' and 'environmental organisation'. The definitions indicate that the term 'environment' has to be interpreted broadly but is limited to physical phenomena. The term undoubtedly encompasses natural environment, such as forests or ambient air. More controversial, in contrast, is the extent to which it covers the built environment. According to the explanatory memorandum, the term should be taken to encompass the elements of human-created environment that are similar to the natural environment, such as city parks ${ }^{* 2}$ but the extent of the right should be clarified in the process of codification of building and planning law. Codification of these areas of law was completed in $2015^{*} 43$, but, regrettably, this has not resulted in any significant clarification of the scope of the GPECA's $23 .{ }^{*} 44$

\subsection{The concept of health and well-being needs}

The GPECA's §23 is titled 'Right to environment that meets health and well-being needs'. These needs are not defined in the GPECA. The concept is vaguely outlined in the explanatory memorandum, which emphasises that the Parliament ought to discuss its limits. ${ }^{*} 45$ It appears that no such discussion took place. In any case, the wording of the provision was not altered.

The question of which needs are worthy of protection is not easy to answer. Inter alia, this can be seen in the discontinued practice of the Supreme Court by which standing was allowed on the basis of certain interest. The last relevant case pertained to the potential impacts of extracting sand from the seabed. The person who brought the action lived about two kilometres from the planned extraction site and was a fisherman. The court panel was divided on the question of whether an important interest was at stake for this person. ${ }^{*} 6$

In this context it may be useful to consider which kinds of environmental interests are protected by environmental law in general. Brennan van Dyke has divided such interests into three categories: 1) the right to inviolable integrity of the person, including the person's physical being and the person's property; 2) aesthetic sensibilities and recreation interests of humans; and 3) the interests of future generations and well-being of non-human life. ${ }^{*} 47$ If only the first category is included, what the GPECA's §23 provides for would resemble a traditional basic right. The problem is that it would be difficult to distinguish this from other traditional rights, such as the right to life, health, property, or one's home. If, on the other hand, all three categories are included, then the right would encompass some interests that clearly are not subjective interests of the person. Therefore, I suggest that an independent subjective right should cover the first two categories of interests but not the third. Moreover, it should be recalled that the drafters of the GPECA sought to codify the existing court practice, which allowed extensive standing in relation to environmental matters while rejecting the idea of actio popularis. If the GPECA's §23 encompassed only the first category of interests, it would probably not lead to a liberal approach to standing, while including all the categories would allow actio popularis.

According to the commentaries on the GPECA, ${ }^{*} 48$ the understanding as to which 'well-being needs' are worthy of protection changes over time and depends on the development of the relevant society and the means available to it. In principle, a person should be protected from environmental nuisances that do not

42 Memorandum (see Note 35), p. 30. Note that the earlier practice of the Circuit Court of Tallinn was focused on the issue of whether members of the public have standing in relation to a matter to do with construction in a 'green space' within a built-up area, such as a city park. See, for instance, Tallinn CCd, 26.6.2008, 3-06-188.

43 Planeerimisseadus (the Planning Act) was adopted on 28 January 2015. - RT I, 26.2.2015, 3. Ehitusseadustik (the Building Code) was adopted on 11 February 2015. - RT I, 5.3.2015, 1.

44 For instance, the Planning Act's $\S 8$ stipulates the principle of improving the living environment, which could be relevant in interpreting GPECA's section. However, the act and its explanatory memorandum (at 200 pages) do not directly refer to GPECA's $§ 23$.

45 Memorandum (see Note 35), p. 30.

46 ALCSCr 13.5.2015, 3-3-1-8-15, para. 16. Dissenting opinion of judges I. Pilving and J. Põld.

47 B. van Dyke. Proposal to introduce the right to a healthy environment into the European Convention regime. - Virginia Environmental Law Journal, 1994/2, p. 330.

48 O. Kask et al. Keskkonnaseadustiku üldosa seaduse kommentaarid. 2., täiendatud väljaanne ['Commentaries on the General Part of the Environmental Code Act., 2nd Updated Edition'), 2015. Available at http://media.voog.com/0000/0036/5677/ files/KeYS_kommentaarid_2015.pdf (most recently accessed on 31.3.2016). 
result in damage to health but are nonetheless disturbing even if the relevant limit values are not exceeded. Impairment in respect of a 'well-being need' may also consist in deprivation of something, such as light (due to the height of neighbouring buildings), water (as in the case of drying up of a well in consequence of mining activities), or access to green areas or the environment in general on the basis of 'everyman's right'. ${ }^{*} 9$ The cautious position taken in the commentary allows interpreting the GPECA's $\S 23$ in terms of the first category of interests: most of the examples consider issues that would be within the scope of traditional rights if the rights were interpreted broadly. In my view, the concept of 'health and well-being needs' should also include individuals' recreation- and aesthetics-related environmental interests. For instance, a birdwatcher, a hiker, a nature photographer, or a botanist studying particular plants should be able to rely on the right in principle.

The very limited court practice of application of the GPECA's $\S 23$ appears to indicate that the notion of 'health and well-being needs' is interpreted broadly. The Tallinn Circuit Court has taken the position that cutting down five trees and building a car park in a yard may, in principle, affect the right of a city resident living in the house to which the yard belongs. ${ }^{*}{ }^{50}$ In another case, that court seemed to accept that using a recreation area in a forest near a town is a health and well-being need of the residents of the town. ${ }^{*}{ }^{1}$

\subsection{The criterion of significant connection}

The first paragraph of the GPECA's §23 stipulates that a person has the relevant right only if he or she has a significant connection with the affected environment. According to the second paragraph, a person has a significant connection with the environment if that person often stays in the affected environment, often uses the affected natural resource, or otherwise has a special connection with the affected environment.

The provision is formulated on the basis of the earlier court practice. ${ }^{*}{ }^{2}$ In several decisions, the Tallinn Circuit Court has used the following formula: 'Environmental impact has personal scope, whether or not other basic rights are affected, if the relevant person has used the affected environmental resource habitually, if that person often stays in said environment, or if the person has a stronger connection with the environment than the rest of the public or the well-being of that person is otherwise significantly affected by the environmental impact." 53 In these cases, the court had to determine which members of the public had standing in relation to an act that affected public green areas, such as a public city park. In the court's view, the living environment of a person includes at least the public space close to that person's home, especially parks and green areas, and also areas where the person habitually spends his or her leisure time. The formula was meant to allow broad standing but avoid actio popularis. In other words, when the concept of 'health and well-being needs' is interpreted broadly, many people may have an interest in the matter. The requirement of significant connection should be understood as a filter for determination of which persons are more affected than others.

A person is more affected if using the environment often. The GPECA does not specify how frequent or intense the use must be. In any case, the person must prove that he or she uses the relevant environment frequently. In the pre-GPECA court practice, living close to the affected environment was considered sufficient proof. ${ }^{*} 54$ This seems to be the case also in the limited court practice of application of the GPECA's \$23. ${ }^{*} 55$ 'Additionally, 'significant connection' can be established on a basis other than use: any 'special connection' would be enough. The GPECA does not specify the meaning of 'special connection'. According to commentary on the act, it could consist of scientific interest, religious views, or ownership of the affected environment. ${ }^{*} 56$

\footnotetext{
49 Ibid., pp. 125-126. The terms of this right are set out primarily in the GPECA’s $\S \S 32-39$ and, in principle, allow every person to use private land and water. This includes use for certain economic activities, such as berry-picking.

50 Tallinn CCr 25.6.2015, 3-15-1266, para. 11.

51 Tallinn CCr 16.12.2015, 3-15-2342, para. 9.

52 Memorandum (see Note 35), p. 31.

53 Tallinn CCr 13.8.2007, 3-07-102, para. 15; Tallinn CCd 18.3.2008, 3-06-1136, para. 10; Tallinn CCd 26.6.2008, 3-06-188, para. 15.

54 Ibid., in paras 17, 12, and 16, respectively.

55 Judgements of Tallinn Circuit Court (see notes 50 and 51), in paras 11 and 9, respectively.

56 See the commentary on the GPECA (see Note 48), p. 127.
} 
The wording of the GPECA's $\$ 23$ raises the question of whether it is enough simply to prove the existence of a significant connection without demonstrating impairment in relation to meeting a particular health and well-being need. In my opinion, the second element has to be demonstrated in principle but its existence can often be presumed. If a link to needs need not be made, individuals could effectively protect any interest, not merely personal interests. For example, if a person habitually walks in a park, his or her right may be affected if the walking paths are rendered inaccessible by building of a drainage system, whereas the right cannot be affected if the drainage system does not affect walking but destroys a habitat of a protected plant species. The effect on health and well-being needs also has to be taken into account in the decision on what constitutes a significant connection. For instance, the more severe air pollution is, the less time a person has to stay in the affected area before being considered to have a significant connection with the affected environment.

In summary, the criterion of significant connection means that impairment of meeting of a need can be generally presumed if the person proves frequent use of the affected environment. In the event of doubt, a link must be established with a health and well-being need; however, there is no requirement set forth in the GPECA for demonstrating that the impairment is serious, obvious, etc.

\subsection{The concept of affected environment}

According to the second and third paragraph of the GPECA's §23, a person must have a significant connection with an affected environment or one likely to be affected. The concept is related primarily to the causal relationship of an administrative act or measure with negative consequences. The wording is problematic for two reasons: it does not expressly provide ex ante protection, and it may be misleading with respect to the negative effects of the act or measure.

The causal relationships can be complicated in environmental matters. Disputes often revolve about the existence or extent of negative impacts that may result from an administrative act, such as granting of an environmental permit. The wording of the GPECA's §23 may give an impression that the right affords protection only if the environment has actually been affected and not in cases of potential negative impacts. However, the provision needs to be read in conjunction with other provisions of the GPECA, such as its statement of the precautionary principle (\$11), which stipulates that in environmental decision-making the impacts of the decisions have to be identified and the risks have to be reduced to the maximum extent possible by means of appropriate precautionary measures.

The negative effects of an administrative act or measure also do not necessarily have to manifest themselves in changes to nature, but this fact is not clearly reflected in the wording of the GPECA's §23. For example, the courts have had to rule on whether a restriction to the use of a recreational area in a forest may affect the right to an environment that meets health and well-being needs. Access to one such area was going to be restricted on as many as 90 days a year in order to ensure that nearby military exercises did not pose a threat to the public. The Tallinn Circuit Court was of the opinion that only actual extensive destruction of the forest could result in infringement of the right and that such destruction was very unlikely. ${ }^{*} 7 \mathrm{In}$ my opinion, the court was misled by the wording of the GPECA's §23, which requires significant connection with the affected environment. While the forest was not affected in the sense that it would be destroyed, the court did not consider that restrictions on the use of such a recreation area are similar to destruction of the forest in their consequence with regard to health and well-being needs: in both cases, the persons concerned cannot use the area for recreational purposes. It is my opinion that the right was affected and the court ought to have determined whether the restrictions to the use of the area were justified.

\subsection{The required quality of the environment}

According to the fourth paragraph of the GPECA's §23, the rights of other persons, public interests, and the characteristics of the region are to be taken into account in assessment of how well the environment meets health and well-being needs. The non-compliance of the environment with health and well-being needs is presumed if a limit value set for the quality of the environment has been exceeded.

The wording of the paragraph is confusing: it is unclear whether it addresses the scope of the right or instead its limitations. One must assume that the first sentence lists the general criteria to be taken into

57 See the judgement referred to in Note 30, para. 9. 
account in limiting of the right, because the rights of other persons or public interest cannot directly determine the scope of another right.

The paragraph offers very little guidance as to the contents of the right: the provision refers only to limit values for the quality of the environment. The definition of this term is provided in the third paragraph of the GPECA's §7: 'Limit value of the quality of the environment' means a limit value established for a chemical, physical, or biological indicator where, for the purpose of protecting human health and the environment, that value must not be exceeded. In other words, the quality of the environment is considered to be inadequate in the case of exceeding of a binding quality-limit value that is relevant for protection of meeting of a health or well-being need. We are unfortunate in that it is not necessarily obvious which indicators are limit values for the quality of the environment. Even if an indicator can be associated with health and well-being needs, it may not qualify because it is not strictly binding. Consider, for instance, the long-term objectives for ozone. There is no definitive date for achieving the objectives; what is stated in the Air Framework Directive is that if the long-term objectives are met, the Member States must, in principle, 'maintain those levels below the longterm objectives and shall preserve through proportionate measures the best ambient air quality compatible with sustainable development and a high level of environmental and human health protection, ${ }^{\prime}{ }^{58}$ Also, while there are numerous limit values, many aspects of environmental quality are not covered by limit values and some elements of it cannot be regulated by way of limit values, such as odours or access to green areas.

The inadequacy of an environment that exceeds limit values is only presumed. It is not clear under what circumstances higher environmental quality has to be guaranteed or lower quality has to be accepted. It could be argued that the provision allows taking an individual person's special needs into account. For instance, if a small percentage of the human population is less tolerant of noise, it could be argued that the persons belonging to this segment of the population have a need for reduction in nightly noise. However, this does not seem to be supported by the wording of the name given to the right. Unlike Article 1 of the Århus Convention, the GPECA's §23 refers to an environment that is adequate not for meeting the needs of the rights-holder but for meeting of needs in general. This implies that the environment must meet the needs of an average person.

It is apparent from the relevant draft materials that the GPECA's §23 was not intended to be so ambiguous. According to the notes on the conception of the GPECA, the right was to be formulated in broad terms but integrated with the specific regulation in the special part of the code. ${ }^{*} 59$ When the GPECA was adopted, in 2011, it was intended to enter into force at the same time as the special part (see §63). However, with the completion of the special part taking much longer than expected, a decision was taken in 2014 to bring the GPECA into force ${ }^{* 60}$ before the next general election, in 2015. Consequently, the GPECA's $\S 23$ is not integrated with specific regulation in sector-specific environmental law, although such a link can be established in the future.

In my view, the vagueness of the GPECA's §23 does not necessarily mean that it is devoid of content and unenforceable beyond the terms on certain quality-limit values. Any legal provision that sets out a requirement related to the environment could be considered to define an acceptable level for the environment. Consider the case of a building permit being issued for construction of a manure-storage facility within the water-protection zone. It could be argued that the provisions of the Water Act and the Nature Protection Act that clearly forbid such construction dictate that this is not an acceptable change in the environment. Any person who intensively uses the river for fishing or recreational purposes could contest the permit on the basis that it violates his or her right to environment. In cases wherein a public authority has discretion e.g., that of a decision on whether a building may be constructed in a green area of a city - it could be argued that the GPECA's §23 requires such decisions to take into account the potential uses of the environment by the public and balance them against other interests. If such consideration is not carried out, this omission could be grounds for annulling the decision. However, by dint of the ambiguity of the right and the principle of separation of powers, the courts should quash the decision only if the error in the application of discretion is evident. This was the approach taken by the Tallinn Circuit Court in its earlier practice. That court

58 Article 18 of Directive 2008/50/EC of the European Parliament and of the Council of 21 May 2008, OJ L 152/1.

59 Keskkonnaseadustiku üldosa seaduse kontseptsioon ['Concept of the General Part of the Environmental Code'], Tallinn 2008 (in Estonian). Available at http://www.just.ee/sites/www.just.ee/files/elfinder/article_files/keskkonnaseadustiku_uldosa_ seaduse_kontseptsioon_2008_1.pdf (most recently accessed on 31.3.2016), p. 60.

60 See the explanatory memorandum to the implementing act for the GPECA. Available at http://eelnoud.valitsus.ee/ main\#6f5UGrFg (most recently accessed on 30.3.2016), p. 1 . 
held that the basic right does not preclude changes in the environment. However, in making the relevant decisions, the public authority has to involve persons whose living environment is affected, must specify the motivation for the decision, and may allow adverse changes only for imperative reasons. ${ }^{* 61}$

\subsection{Remedies}

A right that in theory is extensive has little practical value if its enforceability is limited. The fifth paragraph of the GPECA's §23 stipulates that to uphold the right one can demand that the administrative authority preserve the environment and take reasonable measures to ensure that the environment is in line with the health and well-being needs. The provision clearly indicates that the right is meant to be enforceable. This is evident also from the first paragraph of $\S 30$, which states that the violation of the right is subject to administrative review and administrative court review.

The articulation of the right to demand preservation of the environment resembles the wording for the fundamental duty set out in $\$ 53$ of the Constitution, which requires avoiding harmful action. ${ }^{* 62}$ It is not fully clear whether the demand for preservation in the context of GPECA's §23 may include measures by public authorities to prevent or mitigate damage arising through actions of third parties. In general, the demand to take active measures, such as improvement of access to green areas, is limited to reasonable measures. The reference could be understood as dealing with the necessity of giving special consideration to the burden of action on the public authority and the effectiveness of the action in ensuring the right. ${ }^{* 63}$ It reflects the need for caution in requiring positive action in a situation in which it is unclear what quality of environment is acceptable in ensuring the right.

The GPECA's §23 does not allow directly contesting the actions of private persons, because demands may be addressed only to public authorities. ${ }^{*} 64$ However, actions of public authorities often have immediate consequences for third parties - e.g., contesting the decision to issue an environmental permit affects the holder of the permit. Also, measures for improving the environment may entail obligations of private individuals. For instance, in order to reduce nightly noise in a neighbourhood, the local government may amend the regulations on night clubs or require actions from certain individual pub-owners. According to the commentary on the GPECA, the right of a public authority to demand actions by third parties cannot be based on the GPECA's §23 and has to be derived from other provisions. ${ }^{*} 65$ Consequently the public authority may effectively be rendered unable to take measures that are considered reasonable for ensuring the right.

\subsection{The Supreme Court's criteria for an environmental right and the GPECA's \$23}

According to the Supreme Court, an independent subjective environmental right can emerge when criteria for such an environment and everyone's obligation to tolerate environmental impacts can be fixed in the law. Currently the legal criteria are manifestly inadequate for determining the extent to which the right may be protected. ${ }^{* 66}$

The scope and contents of the GPECA's $\$ 23$ are remarkably ambiguous and do not clarify the relevant legal criteria; i.e., the provision fails the test of the Supreme Court. A possible exception is to be found in certain quality-limit values that are designed for the protection of public health. It would be difficult to argue that with these values too the aim is not the protection of individual-level interests or that none of the values are sufficiently detailed. However, the values are set out not in the GPECA but in specific environmental acts, which existed at the time of the decision of the Supreme Court. In my view, this probably means that the Supreme Court considers the values not to be encompassed by an independent right to environment but, rather, to be one aspect of the right to health protection, which is specified in $\S 28$ of the Constitution.

61 See the judgement referred to in Note 30, para. 11.

62 See the commentary on the Constitution (Note 16), p. 490.

63 See the commentary on the GPECA (Note 48), p. 135.

64 Actions against private persons can be brought to a limited extent under private law. For instance, according to $\S 143$ of the Law of Property Act, one could, in principle, prohibit neighbours from causing non-material environmental nuisances.

65 See the commentary on the GPECA (Note 48), p. 135.

66 ALCSCr 18.6.2010, 3-3-1-101-09, para. 13. 
This right, as are other social and economic rights, is often viewed as amounting to little more than aspirational rhetoric. ${ }^{*} 7$ The Estonian Supreme Court has rejected this view but has emphasised that judicial protection of the right to health protection is limited to the core of the right. The extent of the right depends, inter alia, on the economic capability of the state, and the judiciary shall not replace the legislative or executive powers in exercising of social policy. ${ }^{* 68}$ So far, the focus of the court review by the Supreme Court has been on the right to health care and state assistance, not environmental aspects of the right. However, it is commonly held that the right includes underlying determinants for health, such as environmental conditions. ${ }^{*} 69$ Also, the Supreme Court has been innovative in interpreting basic rights so as to accommodate environmental concerns, although this has met with resistance from more conservative judges. ${ }^{*} 70$

\section{Conclusions}

The purpose with this article has been to examine the basis of the subjective right to environment set out in the GPECA's §23 and analyse its scope and contents to determine whether it satisfies the criteria outlined by the Supreme Court for an independent subjective environmental right.

The conclusion is that the right has no explicit basis in international, EU, or constitutional law. However, some courts, especially the Circuit Court of Tallinn, have recognised a subjective basic right to environment. The GPECA's §23 was intended to codify and expand the existing court practice surrounding the basic environmental right. Court practice changed as the legislative proceedings progressed, but the Parliament did not alter the formulation of the provision.

The scope and contents of the right set out in the GPECA's §23 are noteworthy for their ambiguity. This is a consequence of the regrettable wording for some elements of the right, the Parliament's lack of initiative to discuss the extent of the right, and also the fact that the GPECA was initially designed to be not adopted ahead of the special part but integrated with it. Consequently, the GPECA's §23 fails the Supreme Court's test for an independent subjective environmental right, which requires fixing the scope and content of the right in the law.

The GPECA's §23 relies on several undefined legal concepts. It is proposed that that term 'environment' encompasses the natural environment and elements of the built environment that are similar to the natural environment, such as city parks. The concept of 'health and well-being needs' should essentially encompass all individual-level environmental interests; otherwise, it cannot be distinguished from traditional rights or public interests. The criterion of 'significant connection' should be understood as a filter for singling out persons whose abilities to meet their health and well-being needs are more affected. In general, it is sufficient to prove the existence of this 'significant connection', but a link must be established with a health and well-being need when some doubt exists. The concept of 'affected environment' should not be understood as limiting the scope of the right to cases wherein an actual significant physical change has occurred in the environment.

The only express guidance as to the contents of the right comes in the somewhat vague reference to exceeding of a quality-limit value. However, arguably any legal provision that sets out a requirement with regard to the environment could be considered to define the level acceptable for the environment. Also, it could be argued that the GPECA's $\$ 23$ requires a balancing-of-interests test in connection with any public environmental decision and that this use of discretion is, in principle, subject to court review. Depending on the viewpoint, one could consider the right therefore to be empty and unenforceable or, conversely, to allow enforcement of any environmental requirement that could affect the environment that the relevant person extensively uses. It remains to be seen how the Supreme Court will construe the GPECA’s §23.

67 See, e.g., C. O'Cinneide. Constitutionalization of social and economic rights. - H.A. Garcia, K. Klare, L.A. Williams (eds). Social and Economic Rights in Theory and Practice: Critical Inquiries. London: Routledge 2015, p. 265.

68 See, e.g., ALCSCd 10.11.2003, 3-3-1-65-03, para. 14; Judgement of the Supreme Court in rem 7.6.2011, 3-4-1-12-10, para. 58.

69 See the commentary on the Constitution (see Note 16), pp. 365-366.

70 In a landmark decision, the court found that the right of land-ownership encompasses the interest in preserving a favourable status for the protected habitat of a plant species on the grounds that all plants are part of the immovable. The decision was not unanimous, as one of the justices considered such expansion of the right contrary to the nature of the right. ALCSCd 6.12.2012, 3-3-1-56-12, para. 11; dissenting opinion of I. Koolmeister, paras 1-4. 